\title{
LUIS CARLOS LÓPEZ: UN POETA QUE MIRA A SU ALREDEDOR
}

\author{
LUIS CARLOS LÓPEZ: A POET WHO LOOKS AROUND HIM
}

\author{
Alfonso Rubio \\ Universidad del Valle. Cali, Colombia. \\ alfonru1964@hotmail.com
}

\begin{abstract}
Resumen: Definimos algunas de las características de la poesía del colombiano Luis Carlos López que creemos deben ser punto de partida para comprenderla, atendiendo, sobre todo, a la mirada crítica y realista con que se producía: el empleo de la técnica de la imagen plástica por medio de "tableaux"; de la ironía, el humor, el escepticismo cínico y el sentimentalismo para juzgar las prácticas sociales, religiosas y la moral sexual de la época fundadas en valores tradicionales.
\end{abstract}

Palabras clave: Poesía colombiana, crítica, realismo, ironía, valores tradicionales.

\begin{abstract}
We have defined some characteristics of the work by Colombian poet, Luis Carlos López, which we think should be a starting point for its understanding, mainly keeping in mind the critical and realistic perspective from it was created: the use of plastic images by means of "tableaux"; the irony, humor, cynical skepticism and sentimentalism in judging and criticizing social and religious issues, and the sexual ethics of his age, based on traditional values.
\end{abstract}

Keywords: Colombian poetry, literary criticism, realism, irony, traditional values.

Recibido: 30.10.2014. Aceptado: 28.04.2015. 
[...] bajo su pintarrajeado disfraz de payaso banvillesco, se oculta un desencantado de todo, un misántropo esplénico y cruelmente burlón.

Eduardo Castillo (1961, p. 1119).

\section{Introducción}

TuAn José Arrom (1977, pp. 181-202) reproduce la clasificación propuesta por Federico de Onís (1961) en su ya clásica Antología de la poesía española e hispanoamericana que se publicó en 1934, cuando habla de la generación de 1894 (los nacidos entre 1864 y 1893) dentro del esquema general de las letras hispanoamericanas que plantea. De esta manera, en el mapa de la poesía hispanoamericana de la generación de posmodernistas, Arrom relaciona las mismas orientaciones señaladas por el crítico salmantino: primero, la de un grupo que transita del modernismo al ultraísmo y, luego, la de otro donde se encuentran las escritoras de un poesía intensamente femenina y los poetas que reaccionan hacia la sencillez lírica, la tradición clásica, el romanticismo, el prosaísmo sentimental y la ironía, donde aparecen el poeta colombiano Luis Carlos López y el poeta argentino Baldomero Fernández Moreno.

No deja de ser problemática, sin embargo, como bien anota Hervé Le Corre (2001: 10), la constitución de esa nómina de poetas pertenecientes a lo que Federico de Onís llamó "posmodernismo" caracterizado como "reacción conservadora del modernismo". La falta de criterios definitorios y la falta de coincidencia de criterios para definir sus límites cronológicos y tipológicos son algunas de las causas que desorientan el establecimiento de correctas o creíbles clasificaciones en no pocos de estos escritores. Así, Germán Espinosa (2002, p. 50), al hablar de su paisano Luis Carlos López, nos dice que no se le puede considerar estrictamente modernista ni se le puede calificar con los "motes esperpénticos" de "antimodernista" ni "posmodernista", pues esta última voz "posee implicaciones conservaduristas imposibles de aplicar a López". Espinosa prefiere clasificar al poeta cartagenero dentro de un "concepto prevanguardista" y, sin creer en las generaciones, "dejarlo suelto de madrina".

${ }^{1}$ Una buena caracterización de los poetas de esta etapa de transición entre el modernismo y las manifestaciones renovadoras de las vanguardias, puede verse en Le 
Pero sí es constatable en el proceso literario común en que se da esta lírica “posmodernista”, marcada por unos imperativos históricos y estéticos, una renovación de formas y temas que incluso se repite en otras tipologías de escritura como la novela, el cuento, el teatro y el ensayo, lo que hace concluir a Arrom (1977, p. 193) que este florecimiento no fue accidental: "el endémico malestar político, la creciente inquietud social, las alteraciones producidas por la irrupción del capitalismo financiero, los golpes asestados por fuerzas externas y el consiguiente agobio ante un destino incierto, todo lleva a una nueva meditación de los problemas de América y del hombre americano".

En esta dirección y en la dirección, evidenciada aquí, de la que habla Guillermo Alberto Arévalo (1977, p. 21) para calificar a Luis Carlos López y Fernández Moreno, cuando dice que son "poetas de antítesis, realistas por definición, de un escepticismo cínico", poetas "que profundizan con ironía la intimidad de sus países volviéndose hacia las dimensiones privadas de la aldea para oponer desde ellas un lenguaje conversacional y una conciencia histórica al cosmopolitismo modernista", analizamos las "viñetas" del poeta colombiano para apuntar algunas posiciones críticas de su poesía.

Como Borges (1956, pp. 5-6) dijo de Fernández Moreno al comentar su primer título público, Las iniciales del misal (1915), también el poeta colombiano ejecutó, en esa época y ante la tendencia modernista imperante, un acto que calificó de insólito, "un acto que siempre es asombroso [...], que con todo rigor etimológico podemos calificar de revolucionario. Lo diré sin más dilaciones $[. .$.$] había mirado a su alrededor”.$

\section{Viñetas de crítica realidad}

Para el poeta argentino Oliverio Girondo (1891-1967), la costumbre es una perjudicial cualidad que ciega la realidad: "La costumbre nos teje diariamente una telaraña en las pupilas" (“Espantapájaros”, 14). Este es un

Corre, 2001. Desde posiciones flexibles que abordan el texto poético en sí en las coordenadas espacio-temporales, Le Corre analiza sus condiciones de producción y sus modos de construirse e incidir en un mapa histórico (ideológico y formal) diverso, en un entramado de prácticas heterogéneas, a veces divergentes, pero históricamente ubicables en el proceso literario hispanoamericano. 
principio moral y estético que Beatriz Sarlo (1988, pp. 62-63) utiliza para indicarnos que, bajo él, Girondo intenta separarse del "yo lírico" utilizado en la escritura poética: "yo no tengo una personalidad; yo soy un cocktail, un conglomerado, una manifestación de personalidades" ("Espantapájaros", 8) ${ }^{2}$. Sin un "yo lírico" la expresión o la imaginación del poeta puede liberarse del "sentimentalismo, del recuerdo, de la nostalgia, del pasado, de la tradición, de la historia”. El valor se funda entonces en la novedad y los procedimientos poéticos utilizan en la construcción artística básicamente la percepción: "A los mundos interiores Girondo opone superficies, tableaux, fotogramas captados por un poeta-ojo".

La observación de Sarlo nos sirve aquí para oponer la "no personalidad" de Girondo, o sus múltiples personalidades ("no pasa media hora sin que nazca una nueva personalidad", sigue diciendo en el mismo poema 8) al invariable y muy consciente "yo" del poeta colombiano Luis Carlos López. Como Girondo, la técnica de la imagen plástica por medio de superficies, tableaux o fotogramas es utilizada por López no para describir o recrearse en la muestra de costumbres sociales a la manera de los románticos, sino para criticarlas. Poemas como "Cinematográfica" (114) y "Película" (190), revelan en su título el uso de la técnica fotográfica, que posibilita la construcción literaria a base de momentos fijos o retenidos en la memoria. El conjunto visual de la poesía de López constituye en sí todo un álbum de "historietas", sin que este término disminuya en nada su valor evocativo frente al de "Historia". Al contrario, si empleamos este término, propio del lenguaje del cómic, es porque en su obra el estilo de la historieta gráfica, del "cromo", de la "viñeta", del "croquis", del "trazo", de la "calcomanía", de la "nota", de los "apuntes", de la "cartulina postal", se orienta hacia la crítica histórica. Cuando López utiliza este vocabulario para titular sus poemas, lo hace para describir imágenes y situaciones inamovibles, por donde no parece que haya transcurrido el tiempo, "por e-so las co-sas es-tán como es-tán”: "La rústica plazuela del poblacho/ parece bostezar..." (“Croquis lugareño", 188)) y hay un "Domingo de murria, de holgazanería/ parroquial..." (“Cromito", 133); por eso, en la "quieta ciudad" ("Croquis", 156),

${ }^{2}$ Las citas de Oliverio Girondo están tomadas de su libro Espantapájaros, poemas 8 y 14. Particularmente hemos consultado la edición de Girondo (1968, pp. 171 y 183184), donde se encuentran los poemas citados. 
"en el recogimiento campesino,/ que viola el sollozar de las campanas,/ giran, como sin ganas,/ las enormes antenas de un molino" ("Cromo", 108) 3 .

Las escenas que el poeta presencia y contempla son naturaleza (trazos "del natural") con Historia, pero no es preciso preservarlas de su natural desgaste, resguardarlas de un proceso histórico que amenaza con su existencia. Si el tiempo parece anclado ("Todo es lo mismo: ayer/ pasó como ahora pasa") es porque su ciudad natal siente muy marcadamente el peso de la Historia, pero el tiempo, en realidad, sí pasa, pues Cartagena se ha tornado una "absurda necrópolis en ruina", "pues ya pasó, ciudad amurallada,/ tu edad de folletín". No es el tiempo íntimo, aunque éste también a veces deja verse ("sin juventud la cosa está fregada"), sino el tiempo sociohistórico, el tiempo del progreso, el que más se hace presente en la obra de López:

iTodo un vivo montón de carne y hueso que circula febril, entre camiones y mil autos!...iProducto más que loco

del divino progreso, ese progreso que les trajo a los indios cimarrones, con la espada y la cruz, el gonocco!...

(“Calle de Lozano", 211).

El soneto completo "Calle de Lozano" refleja la ambigüedad moral propia de una época en transición que aglomeraba en sus contradicciones infinidad de distintos, viejos y nuevos, prototipos sociales. Sus dos primeras estrofas lo declaran:

Arteria principal en los anales de la ciudad arcaica y futurista, con todos esos bienes y esos males que nos legó la hispánica conquista.

${ }^{3}$ La edición que seguimos para citar al poeta, que incluye los libros De mi villorrio (1908), Posturas dificiles (1909), Varios a varios (1910), Por el atajo (1920) y Poemas no incluidos en libros, es la de Luis Carlos López (1977). A la hora de citar, entre paréntesis, al lado del título del poema incluimos la página de la edición donde éste se encuentra. 
Desde los cuatro puntos cardinales llegan, y allí se cruzan, el turista, la toga, el balandrán, Pedro Urdimales, Venus, Baco, el hampón y el agiotista...

Se remonta al legado de la "hispánica conquista" para situarla en el presente de una Cartagena en circulación febril de "camiones y mil autos", y pensar irónicamente en el futuro ("ciudad arcaica y futurista") que el "divino progreso" depara. El poema parece reflejar lo que Jacques Le Goff plantea, que el presente, el pasado y el futuro se proyectan el uno sobre el otro, que el tiempo unilineal se quiebra en avances y retrocesos, pero conserva en su sustrato, como conserva la heroica ciudad de Cartagena, una estructura de cambio muy lento, la que agobia en su compromiso social a López. Bajo el ritmo dirigente del "sollozar de las campanas" en una "parroquial" ciudad, su cultura, sus costumbres, su tradición, ponen al poeta en contacto con un tiempo histórico que le desconcierta: "ritmos lentos, flash backs, pérdidas y resurgimientos concuerdan mal con el tiempo unilineal en el que todo lo más está acostumbrado a discernir, aquí y allá, aceleraciones o retrasos" (Le Goff, 1983, p. 296).

La religión católica era dueña del presente que le tocó vivir a López, dueña de un lugar simbólico para toda Colombia como era la capital del Departamento de Bolívar, semejante, según el poeta, a una tediosa parroquia: por la "fangosa plaza principal cruza una procesión católica" ("El día de San Ildefonso", 233) y "las mozas y mozos... salen de la iglesia senil" ("En provincia", 161). La religión es el espectáculo provinciano que predica un puritanismo de curato y que siempre aparece asociada a quien la predica ("curas" y "frailes") y a quien la practica, sobre todo, la mujer, primero por la influencia maternal: "Mi madre... me compró un catecismo..., me rayaba la frente con el Por la señal" y "hoy que tengo veinte años cifra su anhelo/ en que oiga misa entera los días de guardar"("Mi madre", 205); y luego por "las muchachas solteronas": las "muchachas de provincia,/ que salen -si es que salen de la casa-/ muy temprano a la Iglesia,/ con un andar doméstico de gansas" ("Muchachas solteronas", 178). Luis Carlos López somete a crítica dos formas de trascendencia, la religión y el erotismo: "Cantan las esquilas en el campanario/ (las mujeres van/ para la misa, sermón y rosario):/ por e-so las co-sas es-tán como están..." (“Despilfarros”, XIX, 142). 
La profunda ironía del último verso, que nos obliga, como el poeta quiere, a ralentizar y entonar su dictado y detenernos en el significado de su contenido: "por e-so las co-sas es-tán como están...”, reforzada además, con los puntos suspensivos (habituales en sus versos) y el título donde el poema, junto a otros, se encuadra ("Despilfarros", XIX, 142), no sólo muestra la imagen de una ciudad anclada en la Historia, sino también la imagen de una moral sexual fundada sobre la virginidad y el matrimonio. El deseo sexual es explícito en la poesía del tuerto: "persigo... el talle flexible de una moza" ("Despilfarros", XV, 141); "Oh, qué moza flexible y sandunguera/ de pueblo, alegre como un cascabel,/ y con algo de avispa y de pantera!.../ -Ojos de brasa y boca de clavel” (“Apuntes callejeros”, 185); "pones aspavientos/ en las provincianas/ vidas que florecen/ como las patatas", le dice a la mujer de "alegre fama" que pasea con el "garbo chulo" ("Pasas por la calle", 157); campesina sandunguera y sabrosa, “... no dejes de acudir al mercado/ con tus rubios cabellos - coliflor en mostaza- / y tus ojos, tus ojos donde anida el pecado..." (“Campesina, no dejes", 171); y a la "maestrita del pueblo", de "boquita roja” y "boquita en flor", que "invita a libar el beso del amor", le dice:

\begin{abstract}
iAh, maestrita linda! Yo quisiera, aun viejo y todo, sin mancar un día, ir a tu escuelita...no para aprender

las viejas ciencias de la calcomanía sino la moderna sexopatía del gran Freud, que enseñas tú sin conocer.
\end{abstract}

(“A una maestrita”, 205).

Aunque es clara la tensión erótica que produce el dualismo realidad/ deseo, muchas veces recreada por medio de claves de la literatura picaresca (léase, como ejemplo, el jocoso poema A Rosalbina), más allá de esa tensión personal, la modernidad y la apertura intelectual de López, son críticas con unas prácticas religiosas arcaicas, de una pura exterioridad escenográfica que finge el espiritualismo. López se niega a tomar en serio a la Iglesia y a la moral sexual de viejos y tradicionales valores católicos: "Mi parienta... desea... oír en ayuna/ su misa y tragarse alguna/ que otra eucarística oblea,// sin tiznar el pensamiento/ con el sexto mandamiento/ pornográfico. Así sea” (“Un caso”, 133). 
En la aburrida ciudad donde no hay "ni una sola ilusión inesperada que brinde ameno rato" porque "no surge un acontecimiento sensacional" ("Tedio de la parroquia", 186), el poeta previene a las "señoritas miedosas" antes de leer su poema titulado "Visión inesperada" (146) con una cita introductoria de Fray Candil: "Las señoritas miedosas pueden/ retirarse, porque lo que sigue/ es verdaderamente trágico”. Durante un paseo en compañía a orillas del mar ("Pasamos a unos metros de un islote"), la visión inesperada en cuestión, para cuya descripción se utiliza, además, un atrevido vocabulario para la época, no es para menos: "Luce un faro que tiene/ la burda forma de un erecto pene/ fenomenal". El final es conclusivo para desligar el acto sexual del pecado y los temores: “... Tal vez// medita en el amor este rapado/ terruño acantilado,/ isolo en su candorosa desnudez".

Prácticas religiosas y moral sexual puestas a debate ideológico y a crítica irreverente por medio de la comicidad y la ironía, que rebajan lo "espiritual”, ritualizado en ceremonias, al nivel del espectáculo mundano atravesado por el deseo:

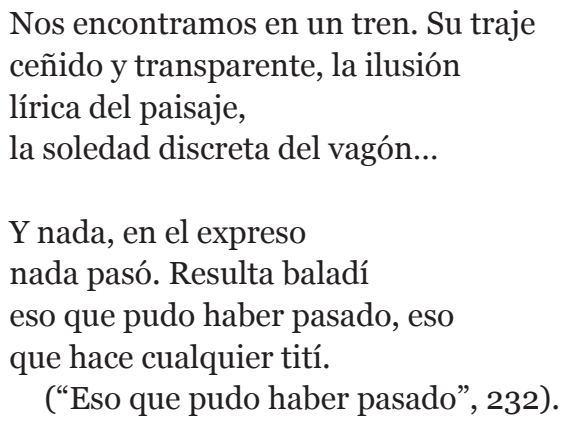

Consciente del diario acontecer y el contexto histórico que lo produce, como poeta de lo cotidiano, López desmitifica los valores y creencias ya caducos de una sociedad de seudoaristócratas que no corresponde a la realidad actual ${ }^{4}$ :

${ }^{4}$ Compárese, como hizo Jaime Mejía Duque (1976, p. 152), el contenido de este poema y toda la obra en general del tuerto, con el poema de León de Greiff escrito en 1914, Villa de la Candelaria, aunque a nadie se le olvidan sus resonancias cuando leemos a López: "Vano el motivo/ desta prosa: nada.../Cosas de todo el día./ Sucesos/ banales./ Gente necia,/ local y chata y roma./ Gran tráfico/ en el marco de la plaza./ 
MI BURGO

Con motivo de tu muerte, Lineas

Señor, ten piedad de tu pueblo y sálvalo de la ruina.

Jeremías, Cap. V, Ver. VII

Los mismos rudimentos de hace tres siglos... Nada de una protesta. Todo completamente igual: callejas, caserones de ventruda fachada $\mathrm{y}$ un sopor, un eterno sopor dominical.

Población anodina, roñosa, intoxicada de incuria -aquella incuria del tiempo colonialcon su falsa nobleza de acéfalos, minada por el fraile y la hueca política venal.

Pobre tierra, caduca tierra que tanto quiero, que hoy rumia mansamente su estolidez, venero de las intransigencias del medio parroquial,

que aún vive, -si es acaso vivir en la atonía de lo incurable-, bajo la risueña ironía de un cielo azul, de un cielo siempre primaveral...

("Mi burgo", 210).

El soneto es un perfecto modelo donde confluyen dos de las características esenciales de toda su poesía: el empleo de una métrica tradicional ${ }^{5}$ y el empleo de una crítica que recurre a la ironía, la que el poeta encuentra en el propio paisaje y en las propias escenas observadas, y también la que el poeta construye a su particular manera humorística. Pero la Historieta

Chismes./ Catolicismo./ Y una total inopia en los cerebros.../Cual/ si todo/ se fincara en la riqueza,/ en menjurjes bursátiles/ y en el mayor volumen de la panza". "La similitud -dice Mejía - se impone hasta en las palabras usadas para transmitir aquella cotidianidad conformista atacándola: 'cosas de todo el día', 'gente necia', 'chismes', "catolicismo'...”.

5 "Mi burgo" es un soneto en alejandrinos, una forma que habían empleado los parnasianos franceses. Esta variante del soneto tradicional en endecasílabos la introdujo al castellano Rubén Darío y fue utilizada frecuentemente por la poesía modernista hispanoamericana. 
de López, que retrata personajes, paisajes, escenas y sentimientos, no se queda en el humor y en la mera descripción; frente a la Historia, frente a ese pasado glorioso de la Cartagena colonial que ahora se ha convertido en el "último asilo de Morfeo,/ rincón del comején y las polillas" ("Calle del Virrey”, 215), el croquis lugareño levantado por el poeta colombiano tiene una fuerza desmitificadora, que ironiza, ridiculiza, vulgariza situaciones y describe la degradación y las contradicciones de unos personajes que oyen "misa de hinojos" y hablan "bien de Voltaire" ("Hongos de la Ribera", 109); "caballeros amables, señoras discretas/ en las frivolidades del five o" clock tea,/ con sombreros que fingen enormes viñetas" ("En la terraza", 107); "seres que portan caretas" de impostura social, que todavía en 1935 emulan la "edad de las mantillas...y de los escarpines con hebillas", siendo ya, en realidad, "fantasmas que van a la Novena y al Sermón" ("Calle del Virrey", 215).

Las costumbres de la Cartagena "aldeana", "tediosa", "soporífera", "parroquial", donde también incluye al "inconsciente populacho", no tejen diariamente una telaraña en las pupilas del poeta. El localismo de Luis Carlos López, como el de otros "antimodernistas", sea el caso el del argentino Baldomero Fernández Moreno con el que, ya vimos, Federico de Onís lo comparó, no es una defensa del atraso de la época, del "descanso sedante" y "dominical", del acomodo y el conformismo social en el medio provinciano, en la "tranquilidad de aldea"; su localismo es, al decir de Guillermo Alberto Arévalo (1977, p. 21), "un poner los pies sobre la tierra, saber en dónde y cuándo se está escribiendo. No es una literatura regionalista. Mira y refleja el mundo, pero no a la manera de los desarraigados; asume lo local y desde esa perspectiva realista se preocupa de lo universal".

Cuando Arévalo señala que Luis Carlos López es el "primer poeta colombiano realista”, está equiparándolo, como hace Gilberto Loaiza (1995) con el cronista antioqueño Luis Tejada Cano (1898-1924), el pequeño "filósofo de lo cotidiano", a esa generación de "hombres nuevos" de América Latina de los que habló José Carlos Mariátegui en La escena contemporánea, que reivindicaban la necesidad de una cultura distinta a las convenciones y tradiciones políticas y éticas heredadas, hombres e intelectuales que introducían la visión de otras culturas europeas en el intento de demoler la tradición intelectual decimonónica americana muy conectada todavía al reciente pasado colonial. También para López "fue vital la relativización 
del unanimismo moral mediante un tenaz espíritu contradictor": es el profundo significado del poema inicial ("Ante todo", 126) de su libro Posturas difíciles, el espíritu contradictor de un libro que "... es, cual lo complejo/ del vivir interior,/ mezcla de mal olor/ y un aroma de flor...”. Si el cronista Tejada Cano se inspiraba en la imagen cínica de un Diógenes en su tonel para "afirmar la personalidad individual", el recurso a la ironía del poeta para defender su intimidad, no olvida al filósofo cínico y en el mismo poema que inicia "Por el atajo" (107), lo cita: "Que no importa, ambulando sin testigo,/ y sin llevar a Diógenes por guía,/ que me ladren, surgiendo de un postigo,/ los anónimos perros de alquería...”.

El cinismo como actitud ante la vida y como crítica de la cultura y la sociedad (pensemos también en el corrosivo caricaturista antioqueño Ricardo Rendón, 1894-1931), pareció ser una reacción común de aquellos intelectuales que en Colombia pugnaban contra las concepciones, costumbres e instituciones de rancio abolengo y al mismo tiempo se mostraban inconformes con el futuro desarrollo del país (Loaiza, 1995, pp. 16 y 90-91)7.

Frente a una sociedad anclada en el pasado, los ideales de López representaban la modernidad occidental del momento. Su actitud cínica podemos ponerla en relación con la actitud de una juventud escéptica del siglo XX señalada por Bertrand Russell (2000, pp. 189-200), para la cual, según causas sociológicas, los viejos ideales de la religión, la patria, el progreso, la belleza y la verdad, ya no inspiran las lealtades del siglo XIX conformista ${ }^{8}$.

\footnotetext{
6 "Versos como cal y canto" llamó Abraham Z. López Penha a los versos de López en su poema-dedicatoria ("Para posturas difíciles") que abre el libro.

7 "En el fondo de toda inconformidad hay siempre un germen de progreso y de liberación”, decía Luis Tejada en su crónica del 3 de septiembre de 1920 "Elogio del espíritu de contradicción" (Loaiza, 1995, p. 90).

${ }^{8}$ Un cinismo para el que Russell encuentra algunas causas en la sociedad del momento: las iglesias se identifican con la defensa de la propiedad y la intensidad de fe religiosa ha disminuido; el nacionalismo, que antes era heroico, se ha vuelto ahora opresivo; el progreso sólo afecta a una cuantificación de artículos de consumo y muchas invenciones modernas tienden a imbecilizar a la gente; en contra de una serena satisfacción que pueda producir belleza, se busca en el mundo moderno producir una significativa inquietud; el hombre moderno tiene conciencia de ser un número en el total estadístico y cuando le asalta el infortunio, "el pasado y el futuro se extienden ante él en una lúgubre procesión de triviales fracasos"; la verdad ha dejado de ser absoluta y a ello ha contribuido el momento actual del pragmatismo, el conductivismo, el psicologismo o la física de la relatividad.
} 
En 1915, Luis Carlos López fundó en Cartagena el diario titulado $L a$ Unión Comercial, dirigido por él y dos de sus hermanos. Era fundamentalmente comercial, pero incluía temas y publicaciones de tipo cultural. Se editaba en inglés y en español y desde la columna editorial López sostuvo debates de temática social y económica. Acerca de este diario, su hermano Domingo relata una nota titulada "Un recuerdo familiar", donde señala la posición de inconformismo y escepticismo del poeta ante el ambiente social que se vivía en Cartagena: "En un ambiente pacato, reaccionario y ultraclerical, la sociedad cerraba sus puertas a todos los vientos de la libertad. El escepticismo y la posición de Luis Carlos tenían que ser, forzosamente, muy incómodos". En tales circunstancias, sigue diciendo su hermano Domingo, Luis Carlos López, a manera de broma que quiso hacer a sus coterráneos, fundó La Unión Comercial (Arévalo, 1977, p. 15).

El hecho refleja lo que Baldomero Sanín Cano (1977 [1928]) dice acerca de la integridad del poeta. Es siempre una misma persona intelectual, pero sonríe de muy variadas formas. Su humor no es un estado de espíritu pasajero, ni una actitud mental que pueda ser representada por el dicho jocoso o el juego de palabras, sino "el resultado de una manera permanente de ver y entender la vida". Esa sonrisa multiforme hay que ponerla en relación con la cantidad de matices de su humor, que ha sido comparado con el de personajes tan distantes en el tiempo como el Arcipreste de Hita, Quevedo, Goya o Charles Chaplin. En esa sonrisa caben términos de distinto tono como "satírico", "grotesco", "irónico", "corrosivo", "sarcástico" o "paródico". A pesar de algunas apariencias, su humor nunca es "tierno", pues entre el hecho parodiado y el poeta se impone la distancia9.

Aunque de muy distinto corte, el humor también es un rasgo permanente en la poesía de Oliverio Girondo y podemos poner a López, como Enrique Molina (1968, pp. 15-16) hace con el poeta bonaerense, en relación con esa "chispa ambivalente del humor, entre la agonía y el orgullo", con un orgullo desafiante que separa y pone por encima de los hechos juzgados la opinión del poeta colombiano: "El humor es una paradójica manifestación

9 De ello habló Estanislao Zuleta (2004, p. 36), de "simpatía y distancia”. López tuvo con Cartagena una "relación bastante tensa: una relación de amor y horror; en una palabra, de humor. Simpatía y distancia, diría él, quien no gustaba de los términos dramáticos y grandilocuentes". 
del deseo de absoluto. Nace de una diferencia de niveles, de una desproporción. La conciencia de las posibilidades infinitas del ser en pugna con los límites de la condición humana, hace brotar ese orgullo resplandeciente, como un desafío". En López, el humor tiene un acento particularísimo que en muchas ocasiones llega a dibujar "aguafuertes" grotescos y "se abre entonces como una salida de fuego de la realidad mediocre. No es una evasión, sino una puesta en juicio de esa realidad, un estado de supervigilia”.

Pero por encima de ser un poeta alegre o triste, la sensación natural que produce la lectura de López es la de verdad: "su persona moral e inteligente" se enriquece con la contemplación y el sentimiento que le produce la observación de la realidad inmediata contemplada bajo el prisma de un temperamento "desinteresado, claro y vivaz". En sus poemas se siente la palpitación y las contradicciones de la vida moderna. Simpatizante del liberalismo de Rafael Uribe Uribe y del republicanismo de Carlos E. Restrepo, López también fue crítico con ellos y con su imposibilidad de una gobernabilidad adaptada a los tiempos. Comprometido con su país, así concluye el ensayista antioqueño Sanín Calvo el Prólogo que hizo a la segunda edición de Por el atajo en 1928: "Esta cosa insípida, gris, blanda y desarticulada que es la vida política de Colombia en los últimos treinta años, está admirablemente vertida por la poesía insuperable, por el humor penetrante y sano de Luis C. López" (Sanín Calvo, 1977 [1928], pp. 694). Vida de "hueca política venal", la llamó el poeta en el poema "Mi burgo" (211).

El mundo que el poeta juzga pasa por un yo lírico que se identifica con el yo personal e íntimo que ha "mamado la leche de mi raza". Es, de todas las formas, un yo contradictorio que en la "... ciudad arcaica y futurista,/ con todos esos bienes y esos males/ que nos legó la hispánica conquista” no puede despegarse de sus raíces familiares, no puede despegarse, como Beatriz Sarlo nos decía de Oliverio Girondo, del sentimentalismo, del recuerdo, de la nostalgia, del pasado, de la tradición, de la historia:

iPobre casa de mis antepasados! Si pudiera comprarte, si pudiera restaurar tus balcones y tejados, y por el caracol de tu escalera

subir a tus salones empolvados, para en tu soledad, casona austera, 
revivir episodios olvidados teniendo en tu zaguán loro y portera...

(“A mi casa”, 219).

Pero esa misma casa familiar se ha vuelto hoy "esqueleto, refugio de vampiros y lagartos". En realidad, el poeta utiliza el sentimentalismo y sus connotaciones temporales para ridiculizarlo. Su sistema crítico se sostiene a lo largo de toda su obra por dos logrados hechos:

1. La recreación de un microcosmos de ambiente "rural”, "provinciano", "parroquial”, "pueblerino", "lugareño", por donde desfilan paisajes (De tierra caliente, Añoranza, Fresco amanecer, Toque de oración, Paseo matinal, etc.) y personajes como los del poeta norteamericano Edgar Lee Masters (1868-1950) de su Antología de Spoon River (1915), una obra crítica con el aldeanismo, su estrechez de miras y su puritana hipocresía moral. Personajes (el juez municipal, el barbero, el veterinario, el alcalde, Pepe el zagalón, la señora muy devota, el zapatero remendón, la campesina, la maestrita, la esposa del banquero o don Ernesto, el hacendado y ganadero) que no están muertos, pero como si lo estuvieran, pues la cantidad de adjetivos utilizados para producir sensaciones de parálisis permanente ("descanso sedante", “somnífera canción”, "soporífera aldea”, “ambiente letal”, etc.) es más que significativa para describir un presente que no termina de despegarse de unas formas de vida ya ahistóricas y absurdas.

2. El uso constante de una ironía descarada para juzgar a esos personajes y a sus actos en su medio natural de vida y en su "rutina cotidiana". La ironía es un agudo recurso de rebeldía que hace latente el empleo del juicio para trascender y universalizar ese microcosmos de personajes prototípicos que todavía hacían parte de creencias atrasadas.

Las cosas están ahí, en la escena citadina, pero la relación simbólica que establece con ellas no es de propiedad ni de apropiación. Bajo un común discurrir del que Luis Carlos López también hacía parte, también es común el derecho de la percepción. La escena en su ciudad de provincias es autosuficiente, en ella los actores y las cosas se desenvuelven según el lugar que ocupan y la actividad habitual que desarrollan. La escena vale 
por sí misma, pero López le adhiere la dimensión simbólica de la Historia para criticarlas.

Ligada inevitablemente a la ironía, el humor como arma crítica de una sociedad sumida en una "égloga tropical”. Ironía y humor como fundamentos, nos dice James J. Alstrum (1986), de la antiliteratura. Comparando a López con el poeta chileno Nicanor Parra de Poemas y antipoemas (1954) y remontándose a un oportuno modelo de antipoesía, el Libro de buen amor de Juan Ruiz (1283-1350), el Arcipreste de Hita, el crítico norteamericano define a López como el "antipoeta" de su época. Su escritura narrativa y satírica se inscribe en un arte dialéctico contrapuesto a un lenguaje poético tradicional de artificialidad y hermetismo retórico. La antiliteratura "rechaza la noción de que una obra literaria sea autosuficiente o autónoma en relación con la realidad social que le rodea" (Alstrum, 1986, p. 2). Los rasgos paródicos, satíricos y hasta grotescos de un lenguaje narrativo que utiliza el estilo del habla cotidiana y conversacional para conseguir descripciones concisas, subrayan "un retorno hacia lo épico pero con un enfoque cómico y autobiográfico sobre el personaje-creador, que es un antihéroe patético que le cuenta al lector sus fracasos y desventuras a la vez que incluye una autocrítica de su propia escritura y de su papel como autor" (Alstrum, 1986, p. 2): “... Mas dejo al irme -amén de lo que dejo:/ salud, papel moneda- este librejo/ y otros librejos sin literatura,// que no valen siquiera un estornudo,/ para que tú, lector hueco y panzudo,/ los tires al barril de la basura” (Poema inicial (166) del libro Por el atajo, del año 1920).

Roberto Fernández Retamar (1995, pp. 174-175) ya señaló que, aunque emparentadas, "antipoesía” y "poesía conversacional” no son lo mismo. Por oposición las define así: la burla y el sarcasmo de la antipoesía frente a la tendencia por lo grave, sin excluir el humor, de la poesía conversacional; el descreimiento (lo escéptico) frente a la afirmación en sus creencias religiosas o políticas; el sentido demoledor con que se vuelve al pasado frente a su evocación con cierta ternura que logra la poesía conversacional a la vez que ésta también es capaz de mirar al tiempo presente abriéndose al porvenir; la incongruencia frente a la sorpresa o el misterio por lo cotidiano; y una retórica cerrada sobre sí y transmisible frente a la dificultad de encerrar en fórmulas a la poesía conversacional, más apta para moverse hacia nuevas perspectivas. 
Conjugando esa suma de caracteres de un tipo de poesía (antipoesía) y de otro (poesía conversacional) con los que se podría definir la poesía de Luis Carlos López, el crítico y poeta cubano habla de "una poesía a la que corresponde un nombre que no debemos temer emplear: un nuevo realismo" (175), un término que aplica para caracterizar cierta poesía que estaba dándose a fines de los años 60 del siglo $\mathrm{XX}$, un realismo que se enriqueció, dice, con la conquista de la poesía de los últimos cuarenta o cincuenta años. El realismo de López, su antipoesía y su poesía conversacional, utiliza recursos que mezclan lo lírico y lo prosaico: versos entrecortados de métrica irregular dentro de las formas métricas tradicionales, la combinación de la lírica popular y la poesía culta, el uso frecuente del encabalgamiento, la inclusión del diálogo en el poema ("Me dice usted: -'Escríbame un soneto'./ Y para complacerla, necesito/ salir, como Argensola del aprieto.../ -Vamos, ya tengo un mal cuarteto escrito...") ${ }^{10}$, la descripción poética de un aparente hecho anecdótico, o el explícito tono conversacional de sus poemas titulados como "Cartas" ("Carta a Luis C. López", 261; "Carta a Don Jorge Mateus", 263; "Carta segunda”, 265; "Epístola tercera”, 270272; etc.), que es el idóneo tipo documental para reflejar y explayarse o recrearse con la ironía:

Pues oye: si has venido

-según reza tu epístola- a la Aduana

de Reconocedor, aquí me pongo,

sin sentido

común y sin cristina

pasividad de hongo,

a tu disposición. Y te convido

no sólo a merendar huevos de iguana,

sino a un boccato arzobispal: iMondongo!

(“Carta a Don Jorge Mateus", 263).

${ }^{10}$ Las coincidencias con el poema de 1965 titulado A Eduardo Mendoza Varela que me ha mandado hacer un soneto, de Jaime Jaramillo (1991, p. 167), otro poeta que fundamenta su crítica social en la ironía, son evidentes: "Ya que hacer un soneto me has pedido,/ Trataré de probar si tengo suerte,/ Y puedo al fin, Eduardo, complacerte/ Con un soneto o algo parecido...”. 


\section{Conclusión}

Luis Carlos López miró a su alrededor y analizó la vida de una ciudad que, siendo la suya, no representaba únicamente los valores morales y sociales de una determinada localidad. Cartagena fue en su poesía un fuerte lugar simbólico que, desde su íntimo conocimiento y el crítico juicio de su mirada, representaba el contexto histórico y social de todo un país.

La poesía de López es rica en matices temáticos y estilísticos que todavía están sin descubrir del todo. Cada vez que nos acercamos a ella, más nítida se nos manifiesta la sociedad del momento, representada y criticada a través de una mirada incisiva que, gracias a su humor de múltiples caras, no resulta molesta, al menos para quien sonríe, como nosotros, de sus caricaturas.

Referencias aquí citadas como las de James J. Alstrum y Guillermo Alberto Arévalo que, desde un realismo acerado, caracterizan correctamente la poesía del poeta colombiano, han sido punto de partida para hablar, desde nuestro particular punto de vista, de algunos de sus aspectos que complementan observaciones ya vertidas por la crítica: el empleo de la técnica de la imagen plástica por medio de superficies, tableaux, fotogramas o viñetas; el sentido de las prácticas religiosas de la época, reflejo de la imagen de una moral sexual fundada en valores tradicionales; y el humor y el escepticismo cínico conseguidos por medio de la ironía y variados recursos estilísticos.

\section{Referencias}

Alstrum, J. J. (1986). La poesía de Luis Carlos López y la tradición de la antiliteratura en las letras hispánicas. Boletín Cultural y Bibliográfico de la Biblioteca Luis Ángel Arango del Banco de la República de Colombia, 7, XXIII. En http://publicaciones.banrepcultural.org/index.php/boletin_ cultural/article/view/3140/3228.

Arévalo, G. A. (1977). Introducción a López, Luis Carlos. Obra poética [Edición crítica de Guillermo Alberto Arévalo]. Bogotá: Carlos Valencia Editores.

Arrom, J. J. (1977). Esquema generacional de las letras hispanoamericanas. Ensayo de un método. Bogotá: Instituto Caro y Cuervo.

Borges, J. L. (1956). Veinticinco años después de "Las iniciales del misal”. El 
Hogar, Buenos Aires, 14 de junio de 1940. En Introducción a Baldomero Fernández Moreno, Versos de Negrita (pp. 5-8). Buenos Aires: Deucalión.

Castillo, E. (1961). Luis C. López. Boletín Cultural y Bibliográfico de la Biblioteca Luis Ángel Arango del Banco de la República de Colombia, 11, IV, 1118-1122.

Espinosa, G. (2002). Luis C. López. En Ensayos completos, 1989-2002 [Tomo II] (pp. 31-55). Medellín: EAFIT.

Fernández Retamar, R. (1995). Para una teoría de la literatura hispanoamericana. Capítulo "Antipoesía y poesía conversacional en Hispanoamérica”, pp. 159-176. Bogotá: Instituto Caro y Cuervo.

Girondo, O. (1968). Obras completas. Introducción de Enrique Molina. Buenos Aires: Editorial Losada.

Jaramillo Escobar, J. (1991). Sombrero de ahogado. Poemas de tierra caliente. Medellín: Editorial El Propio Bolsillo.

Le Corre, H. (2001). Poesía hispanoamericana posmodernista. Historia, teoría, prácticas. Madrid: Gredos.

Le Goff, J. (1983). Tiempo, trabajo y cultura en el Occidente medieval. Madrid: Taurus.

Loaiza Cano, G. (1995). Luis Tejada y la lucha por una nueva cultura (Colombia, 1898-1924). Bogotá: Tercer Mundo Editores.

López, Luis C. (1977). Obra poética. Edición crítica de Guillermo Alberto Arévalo. Bogotá: Carlos Valencia Editores.

Mejía Duque, J. (1976). Literatura y realidad. Medellín: Oveja Negra.

Molina, E. (1968). Introducción: Hacia el fuego central o la poesía de Oliverio Girondo. En Oliverio Girondo, Obras completas (pp. 9-43). Buenos Aires: Editorial Losada.

Onís, F. de. (1961). Antología de la poesía española e hispanoamericana (1882-1932). New York: Las Américas Publishing Company.

Russell, B. (2000). Elogio de la ociosidad (pp. 189-200). Barcelona: Edhasa.

Sanín Cano, B. (1977). Prólogo $2^{\mathrm{a}}$ edición Por el atajo de Luis Carlos López, 1928. En Baldomero Sanín Calvo, Escritos (pp. 691-694). Bogotá: Instituto Colombiano de Cultura.

Sarlo, B. (1988). Una modernidad periférica: Buenos Aires 1920 y 1930. Buenos Aires: Ediciones Nueva Visión.

Zuleta, E. (2004). La poesía de Luis Carlos López. Medellín: Hombre Nuevo Editores. 